\title{
Antibiotic Susceptibility Profile of Bacteria Isolated from Door Handles of University of Benin Teaching Hospital, Benin City, Edo State, Nigeria
}

\author{
Augustine Brian Odigie ${ }^{1}$, Frederick Osaro Ekhaise ${ }^{1}$, Paul Ikechukwu Orjiakor ${ }^{2,}$, \\ Eze Chibuzor Nwadibe ${ }^{3}$, Odeyemi Adebowale Toba ${ }^{2}$, Odoh Chuks Kenneth ${ }^{3}$ \\ ${ }^{1}$ Department of Microbiology, Faculty of Life Sciences, University of Benin, Edo State, Nigeria \\ ${ }^{2}$ Department of Microbiology, Faculty of Sciences, Ekiti State University, Ekiti State, Nigeria \\ ${ }^{3}$ Department of Microbiology, Faculty of Biological Sciences, University of Nigeria, Nsukka, Enugu State, Nigeria
}

Email address:

paul.orjiakor@eksu.edu.ng (P. I. Orjiakor), brain.van43@yahoo.com (A. B. Odigie)

${ }^{*}$ Corresponding authors

\section{To cite this article:}

Augustine Brian Odigie, Frederick Osaro Ekhaise, Paul Ikechukwu Orjiakor, Eze Chibuzor Nwadibe, Odeyemi Adebowale Toba, Odoh Chuks Kenneth. Influence of Antibiotic Susceptibility Profile of Bacteria Isolated from Door Handles of University of Benin Teaching Hospital, Benin City, Edo State, Nigeria. Journal of Health and Environmental Research. Vol. 4, No. 1, 2018, pp. 35-41. doi: $10.11648 /$ j.jher.20180401.15

Received: January 6, 2018; Accepted: February 16, 2018; Published: March 23, 2018

\begin{abstract}
In recent times, surfaces of hospital environment, constantly exposed to activities of patients and health-care workers, have been identified as potential routes for horizontal dissemination of drug resistant microorganisms of public health significance. This study was conducted to investigate the antibiotic resistance profile of bacteria isolated from samples collected from door handles of various units in University of Benin Teaching Hospital (UBTH), Benin City, Edo State, Nigeria. Out of the 66 door handles sampled and analysed bacteriologically, 68 predominant bacteria distributed among five (5) species of Escherichia coli (30.9\%), Staphylococcusaureus (26.5\%), Pseudomonas aeruginosa (17.6\%), Streptococcus pneumonia (13.2\%) and Bacillus subtilis (11.8\%) were isolated. Kirby Bauer techniques of disk diffusion antibiotic susceptibility test on the isolates using 9 commercial antibiotics according to Clinical Laboratory Standards Institute (CLSI) procedure showed resistance of $P$. aeruginosa to five (5) drugs (Sulfamethoxazole-Trimethoprim, Streptomycin, Ampicillin, Cephalexin and Nalidixic acid), E. coli to five (5) drugs (Ofloxacin, Sulfamethoxazole-Trimethoprim, Ampicillin, Cephalexin and Nalidixic acid), S. pneumoniaeto two drugs (Ampicilin and Nalidixic acid) and $S$ aureus to only Nalidixic acid. Agarose gel electrophoresis carried out on their plasmid DNA revealed detectable fragments in P. aeruginosa and E. coli. After plasmid curing, the isolates became sensitive to Streptomycin, Cephalexin,Ofloxacin, Sulfamethoxazole-Trimethoprim, Ampicillin and Ciprofloxacin. Findings from this study suggest the presence of plasmid mediated multi-drug resistant $P$. aeruginosa and $E$. coli on surfaces of hospital door handles. Hence, public education on proper personal hygiene and disinfection techniques are recommended in hospitals.
\end{abstract}

Keywords: Antibiotics, Door Handles, Plasmid, Bacteria

\section{Introduction}

A hospital is a designated health care institution for diagnosis and treatment of patients. A teaching hospital combines health care assistance to patients with teaching of medical students and nurses. Over the years, hospital environment and surfaces have been known to be reservoirs of a number of pathogens [1] [2]. The routes of hospital acquired infections were found to be mainly by direct handto-hand contact between health care workers and patients as well as indirect contact from contaminated surfaces used by others workers or patients [3] [4]. In recent times, some multi-drug resistant pathogens have been isolated from inanimate surfaces that were constantly exposed to patients and health care workers. Report of the spread of methicillin- 
resistant Staphylococcus aureus (MRSA) and vancomycinresistant Enterococcus sp. (VRE) in samples collected from hospital environment has been on the increase in recent time [5] [6].

In Morocco, the presence of Staphyloccocusaureus, Pseudomonas sp, Klebsiellasp., were reported to be widely disseminated on inanimate surfaces and on the hands of health professionals and patients [7]. According to [8], there has been isolation of predominantly multi-drug resistant Pseudomonas aeruginosa, Enterobactercloacae, and Klebsiella pneumonia from hospital surfaces and environment. Considering the hazard posed by rising cases of drug-resistant pathogens to visitors, patients and health care workers within the hospital environmental, it is pertinent too for researchers to constantly monitor the susceptibility profiles of microbial isolates from hospital environments.

Previous study from University of Benin Teaching Hospital, Benin City, Nigeria, revealed poor quality of the outdoor and indoor air as well as the door-handle surfaces [9] [10]. This is of public health importance, considering the potential hazards posed by the pathogens in such environmental. Hence, this study was carried out to investigate the antibiotic-resistance profiles of bacterial isolates from door handle surfaces in the University of Benin Teaching Hospital, Benin City, Edo State, with a view to providing information needed for proactive action.

\section{Materials and Methods}

\subsection{Study Site}

The study site for this research project was University of Benin Teaching Hospital (UBTH), Benin City, Edo State, Nigeria. The study was carried out after permission was obtained from the hospital authorities and ethical clearance from the Committee on Human Research and Publication, University of Benin Teaching Hospital (UBTH), Benin City. The sampling locations were the door handles of the Emergency Ward, Paediatric Ward, Male and Female Surgical Wards, Intensive Care Units, Theatre, Consultant out Patient Department (COPD), Microbiological Laboratory, Revenue Section, Pharmacy Department, and General Toilet found within the teaching hospital.

\subsection{Sample Collection}

A total of 66 samples of the door handle surfaces were collected over a period of six months (between May, 2015 and October, 2015). The samples were collected with the aid of sterile swab sticks moistened with sterile normal saline. The collected specimens were labeled appropriately and then transported in ice packed boxes to the Laboratory for microbiological analyses.

\subsection{Bacteriological Analysis of Sample}

Each swab stick was incubated overnight in $10^{-1} \mathrm{ml}$ normal saline to encourage the growth of microorganisms. The original samples were serially diluted and plated on sterile
Nutrient agar using pour plate techniques. The plates were incubated at $37^{\circ} \mathrm{C}$ for $24 \mathrm{~h}$. The characteristic distinct colonies were isolated and purified by sub-culturing on nutrient agar to obtain pure culture isolates. The cultural, morphological, biochemical and physiological characterization of the bacterial isolates were carried out according to the methods of [11].

\subsection{Determination of the Antibiotic Susceptibility Pattern of the Bacterial Isolates}

The antimicrobial susceptibility tests of the isolates were determined using the disc diffusion test according to the methods of [12] [13] [14]. An inoculum of each isolate (approximately $1 \times 10^{8} \mathrm{cfu} / \mathrm{ml}$ ) was developed using the McFarland Standard and aseptically streaked evenly on the surface of sterile Mueller-Hinton agar. Nine (9) commercially prepared antibiotic disc made up ofPefloxacin $(10 \mu \mathrm{g})$, Ofloxacin $(10 \mu \mathrm{g})$, Streptomycin $(30 \mu \mathrm{g})$, SulfamethoxazoleTrimethoprim $(30 \mu \mathrm{g})$, Cephalexin $(10 \mu \mathrm{g})$, Nalidixic acid, Ciprofloxacin $(10 \mu \mathrm{g})$, Ampicilin $(30 \mu \mathrm{g})$, AmoxicillinClavulanic acid and $(30 \mu \mathrm{g})$, Gentamicin $(10 \mu \mathrm{g})$, were aseptically placed on the seeded plates. Plates were incubated at $37^{\circ} \mathrm{C} \mathrm{C}$ for $16-24 \mathrm{~h}$. The zones of growth inhibition around each of the antibiotics disc were measured to the nearest millimeter. The zone diameters of the drugs were interpreted using the criteria published by National Committee for Clinical Laboratory Standards [15].

\subsection{Plasmid Profile Test}

Plasmid analysis was performed on bacterial isolates on the basis of their antibiotic resistance phenotypes. All isolates selected for plasmid analysis were those with multiple resistant characteristics. The modified alkaline lysis method for plasmids extraction described by [16] was used for extraction of plasmid. Organisms were grown in $2.5 \mathrm{ml}$ of nutrient broth and incubated at $35^{\circ} \mathrm{C}$ for $18 \mathrm{~h}$. After incubation, $0.5 \mathrm{ml}$ of each culture was transferred into $1.5 \mathrm{ml}$ Eppendorf tubes for plasmid extraction; glycerol was added to the remaining and stored at $4{ }^{\circ} \mathrm{C}$. The Eppendorf tubes were centrifuged at $6000 \mathrm{rev} / \mathrm{min}$ for 15 seconds after which the supernatant was carefully removed with the use of finetip automatic micropipette and the cell pellet was thoroughly suspended in the $100 \mu$ l of lysozyme solution. The pelletlysozyme mixture was incubated at $0^{\circ} \mathrm{C}$ for $30 \mathrm{mins}$ after which $200 \mathrm{ml}$ of the alkaline sodium doedecylsulphate (SDS) solution was added and gently vortexed. This suspension was almost clear and slightly viscous. The tube was maintained for 5 mins at $0^{\circ} \mathrm{C}$ and then $150 \mu$ l of sodium acetate solution was added. The content of each tube was gently mixed for about six to seven seconds during which clots of DNA were observed in each tube. The tubes were maintained at $0^{\circ} \mathrm{C}$ for 60 mins to allow most of the protein, high molecular weight RNA and chromosomal DNA to precipitate. The tubes were centrifuged for $5 \mathrm{mins}$ at $15,000 \mathrm{rev} /$ minute to yield a clear supernatant; about $0.4 \mathrm{ml}$ of the supernatant was removed from each tube and transferred into smaller centrifuge tubes. 
One milliliter $(\mathrm{ml})$ of cold ethanol was added and held at $20^{\circ} \mathrm{C}$ for $30 \mathrm{mins}$, the precipitate was then collected by centrifugation at $6000 \mathrm{rev} / \mathrm{min}$ for $2 \mathrm{mins}$ and the supernatant was removed by aspiration.

The pellet was dissolved in $100 \mu \mathrm{l}$ of $0.1 \mathrm{M}$ sodium acetate/0.05 TrisHCl ( $\mathrm{pH} \mathrm{8)}$ and re-precipitated in 2 vols of cold ethanol and allowed to stand for $10 \mathrm{~min}$, at $20^{\circ} \mathrm{C}$, the precipitate was again collected by centrifugation as described earlier. The pellet was dissolved in $40 \mu \mathrm{l}$ of water and then $10 \mu$ of sample buffer was added, about $10-20 \mu 1$ of plasmid DNA in solution was applied to an agarose gel for electrophoresis. One percent agarose was prepared and loaded into electrophoresis chamber containing between $12-$ 18 wells. The electrophoresis buffer that was used which contained $40 \mathrm{mM}$ Tris, $20 \mathrm{mM}$ sodium acetate, $2 \mathrm{mM}$ EDTA, adjusted to $\mathrm{pH} 7.8$ with acetic acid. The buffer contained $25 \%$ sucrose, $5 \mathrm{mM}$ sodium acetate, $0.05 \%$ bromophenol blue and $0.1 \%$ SDS. Electrophoresis was allowed to proceed at room temperature until bands become visible at the positive end of the chamber. After electrophoresis, gels were stained with ethidium bromide $(1 \mu \mathrm{l} / \mathrm{ml})$ and viewed under UV Tran illumination.

\subsubsection{Plasmid Curing and Antibiotic Analysis}

To cure the plasmid DNA, a loop full of an overnight bacterial culture cultivated in nutrient broth containing antibiotics for $24 \mathrm{hrs}$ at $37^{\circ} \mathrm{C}$ was inoculated into $1 \mathrm{ml}$ of nutrient broth and incubated for 18-24 hours. Sodiumdeodecyl-sulphate (SDS) curing agent was then added to bring the concentration to $1 \%(\mathrm{w} / \mathrm{v})$ SDS, followed by incubation at $7^{\circ} \mathrm{C}$ for $24 \mathrm{hrs}$. Freshly prepared nutrient broth was then inoculated with an aliquot of cured culture and incubated for $24 \mathrm{hrs}$ at $37^{\circ} \mathrm{C}$. Antibiotic susceptibility profile for all isolates were then repeated as described above using the disc-diffusion technique on Mueller-Hinton agar [17]

\subsection{Statistical Analysis}

Two-way ANOVA without replication was used to determine the significant difference between the frequencies of occurrence of isolates on door handles at different locations in the hospital including general toilet. Data were summarized and analyzed using SPSS software 16 version.

\section{Results and Discussion}

The predominant bacteria that were isolated and characterizedfrom the door handle surface samples included threeGram-positives (Staphylococcus aureus, Stretptococcuspneumoniaeand Bacillus subtilis) and two Gram-negatives (Escherichia coli and Pseudomonas aeruginosa). The most prevalent bacterium was $E$. coli (30.9\%), followed by $S$. aureus (26.5\%), with $B$. subtilis(11.8\%) being the least (Figure 1). The prevalence of S. aureus, Pseudomonas sp., E. coli and Streptococcus sp. has been reported in earlier studies as the dominant bacteria on inanimate surfaces and on the hands of health care professionals and patients [7]. The presence of different species of Bacillus spp. has been reported in outdoor and indoor air samples collected from UBTH, Benin City, Nigeria [9]. Recently, [8] reported the isolation of predominant multidrug resistant $P$. aeruginosa and other Gram-negative bacteria from hospital environment. Hence, our findings are in agreement with earlier findings. The finding of $E$. coli as the most frequent bacterium is not consistent with earlier reports, which shows $S$. aureusas the most prevalent isolate from samples of surfaces of hospitals and public institutions in Nigeria [18] [19] [20] [21]. The significant levels of E. coli and $S$. aureus in this study suggest the need for intensification of environmental sanitation and personal hygiene within hospital environments.

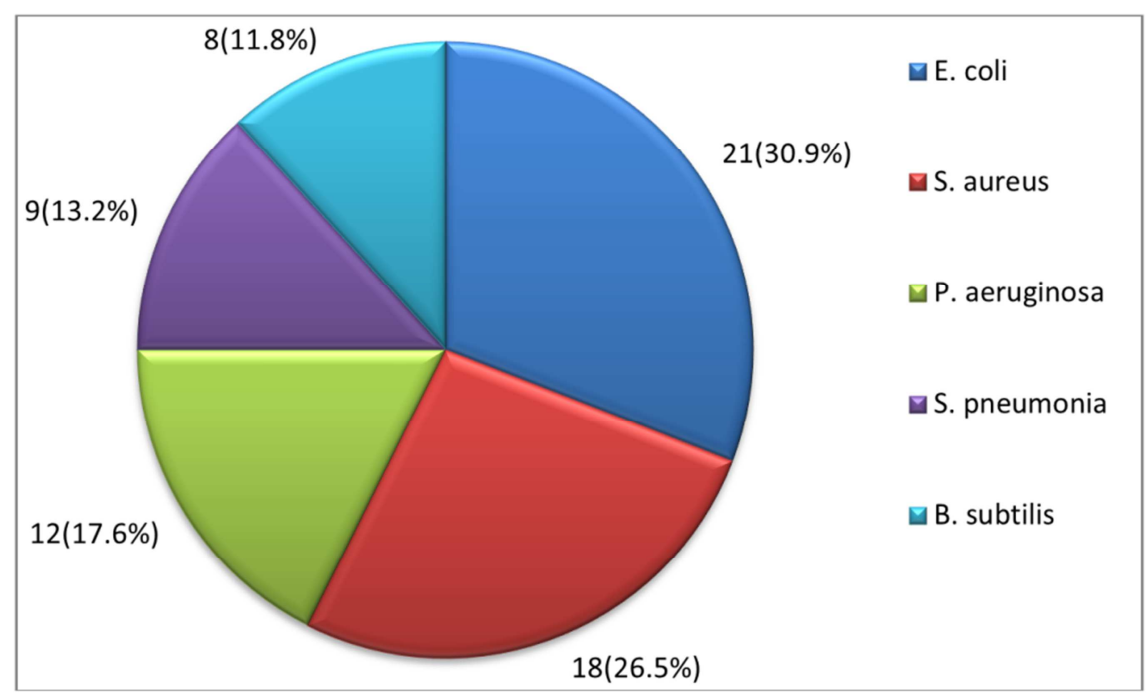

Figure 1. Percentage of bacteria isolated from door handles of UBTH.

The five predominant bacterial isolates were subjected to susceptibility test using some commonly used commercial antibiotic discs and the results revealed varied susceptibility patterns. Escherichia coli and P. aeruginosa were found to demonstrate remarkable resistance to SulfamethoxazoleTrimethoprim, Cephalexin, Ampicilin, and Nalidixic acid 
(Figure 2 and 3). Most isolates of $S$. pneumoniaedemonstrated greater than $50 \%$ resistance to Gentamycin, Ampicillin and Nalidixicacid (Figure 4). Only Sulfamethoxazole-Trimethoprim and Nalidixic acid were found not to significantly inhibit the growth of $S$. aureus (Figure 5). Bacillus species were generally the most susceptible isolates to all the antibiotics (Figure 6). Finings from the pre-plasmid curing antibiotic analysis suggest that both $E$. coli and $P$. aeruginosawere resistant to majority of the antibiotics, followed by $S$. pneumoniae, S. aureus and $B$. subtilis. The multi-drug resistance observed in most isolates of $E$. coli and $P$. aeruginosais in line with the earlier studies that reported them as among the major Gram-negative mulitidrug resistant isolates from hospital and environmental samples [7] [8] [21]. According to [14] [22], these bacteria demonstrate antibiotic resistance as a result of the presence of the efflux system genes that confer hyper expression of Mex-AB-Oprm efflux pump leading to exclusion of antibiotics activities. The relative low resistance of most isolates of S. pneumoniae, S. aureus, Bacillus subtilisfurther support earlier reports that majority of multi-drug resistant bacteria from hospital environment are Gram-negative [7] [8] [21] [23]. However, other studies have reported high levels of Gram-positive multi-drug resistant bacteria from hospital environment [22]. The rising cases of antibiotics resistance strains has been attributed to misuse and abuse of drugs, which create a favourable environment for both the environmental opportunistic bacterial to acquire resistant genes [7] [13]. The negative implications of infections caused by multi-drug resistant strains include magnified adverse disease outcomes, treatment failures, increased cost of treatments and death [24].



Figure 2. Pre-curing Antibiotic Susceptibility Pattern of E. coli isolates.

$\mathrm{PEF}=$ Pefloxacin $(10 \mu \mathrm{g}), \mathrm{OFX}=$ Ofloxacin $(10 \mu \mathrm{g}), \mathrm{S}=$ Streptomycin $(30 \mu \mathrm{g}), \mathrm{SXT}=$ Sulfamethoxazole-Trimethoprim $(30 \mu \mathrm{g}), \mathrm{CEP}=\mathrm{Cephalexin}(10 \mu \mathrm{g})$, $\mathrm{NA}=$ Nalidixic acid, $\mathrm{CPX}=$ Ciprofloxacin $(10 \mu \mathrm{g}), \mathrm{PN}=$ Ampicilin $(30 \mu \mathrm{g}), \mathrm{AU}=$ Amoxicillin-Clavulanic Acid $(30 \mu \mathrm{g}), \mathrm{GN}=\mathrm{Gentamicin}(10 \mu \mathrm{g})$

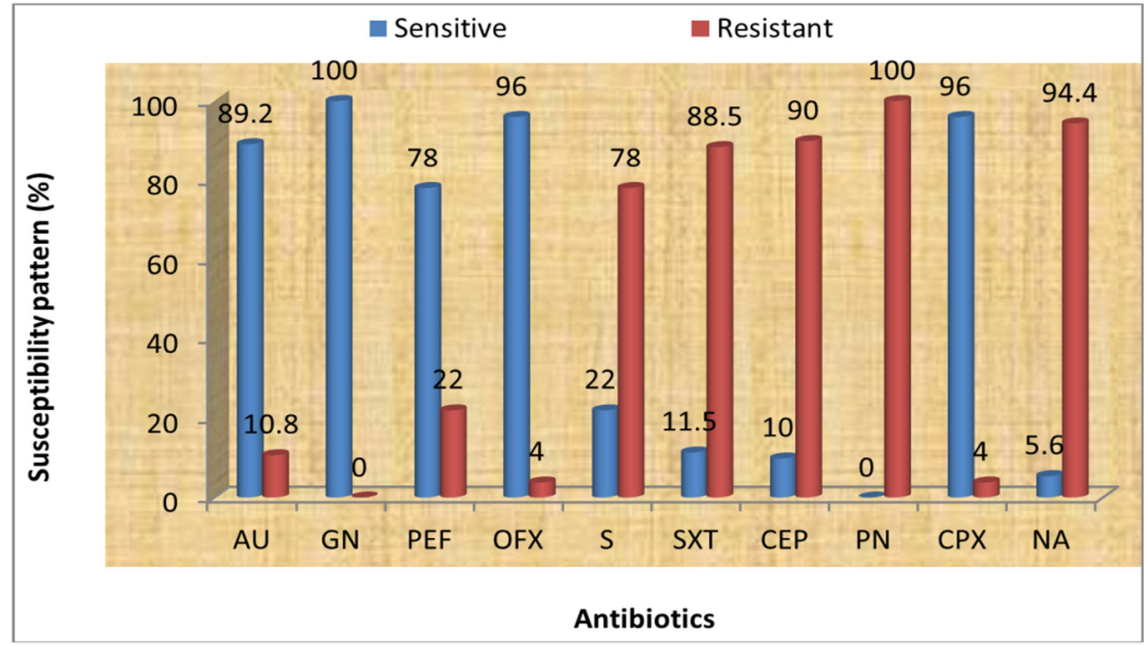

Figure 3. Pre-curing Antibiotic Susceptibility Pattern of P. aeruginosa isolates.

$\mathrm{PEF}=$ Pefloxacin $(10 \mu \mathrm{g}), \mathrm{OFX}=$ Ofloxacin $(10 \mu \mathrm{g}), \mathrm{S}=$ Streptomycin $(30 \mu \mathrm{g}), \mathrm{SXT}=$ Sulfamethoxazole-Trimethoprim $(30 \mu \mathrm{g}), \mathrm{CEP}=\mathrm{Cephalexin}(10 \mu \mathrm{g})$, $\mathrm{NA}=$ Nalidixic acid, $\mathrm{CPX}=$ Ciprofloxacin $(10 \mu \mathrm{g}), \mathrm{PN}=$ Ampicilin $(30 \mu \mathrm{g}), \mathrm{AU}=$ Amoxicillin-Clavulanic Acid $(30 \mu \mathrm{g}), \mathrm{GN}=\mathrm{Gentamicin}(10 \mu \mathrm{g})$ 


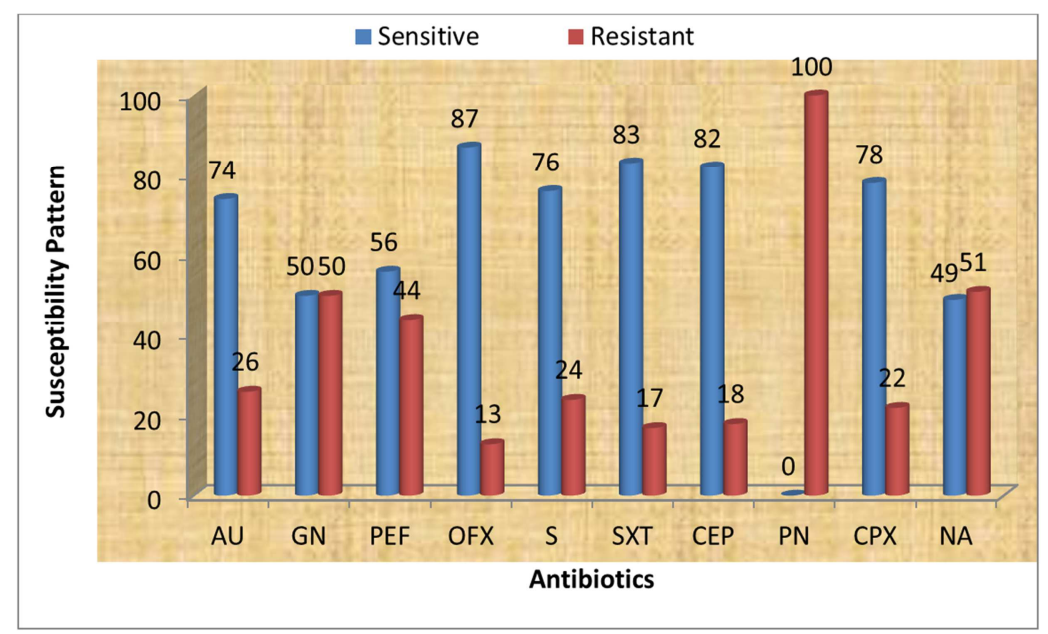

Figure 4. Pre-curing Antibiotic Susceptibility Pattern of S. pneumoniaeisolates.

$\mathrm{PEF}=$ Pefloxacin $(10 \mu \mathrm{g}), \mathrm{OFX}=$ Ofloxacin $(10 \mu \mathrm{g}), \mathrm{S}=$ Streptomycin $(30 \mu \mathrm{g}), \mathrm{SXT}=$ Sulfamethoxazole-Trimethoprim $(30 \mu \mathrm{g}), \mathrm{CEP}=\mathrm{Cephalexin}(10 \mu \mathrm{g})$, $\mathrm{NA}=$ Nalidixic acid, $\mathrm{CPX}=$ Ciprofloxacin $(10 \mu \mathrm{g}), \mathrm{PN}=$ Ampicilin $(30 \mu \mathrm{g}), \mathrm{AU}=$ Amoxicillin-Clavulanic Acid $(30 \mu \mathrm{g}), \mathrm{GN}=\mathrm{Gentamicin}(10 \mu \mathrm{g})$



Figure 5. Pre-curing Antibiotic Susceptibility Pattern of S. aureus isolates.

$\mathrm{PEF}=$ Pefloxacin $(10 \mu \mathrm{g}), \mathrm{OFX}=$ Ofloxacin $(10 \mu \mathrm{g}), \mathrm{S}=$ Streptomycin $(30 \mu \mathrm{g}), \mathrm{SXT}=$ Sulfamethoxazole-Trimethoprim $(30 \mu \mathrm{g}), \mathrm{CEP}=\mathrm{Cephalexin}(10 \mu \mathrm{g})$, $\mathrm{NA}=$ Nalidixic acid, $\mathrm{CPX}=$ Ciprofloxacin $(10 \mu \mathrm{g}), \mathrm{PN}=$ Ampicilin $(30 \mu \mathrm{g}), \mathrm{AU}=\mathrm{Amoxicillin}-$ Clavulanic Acid $(30 \mu \mathrm{g}), \mathrm{GN}=\mathrm{Gentamicin}(10 \mu \mathrm{g})$

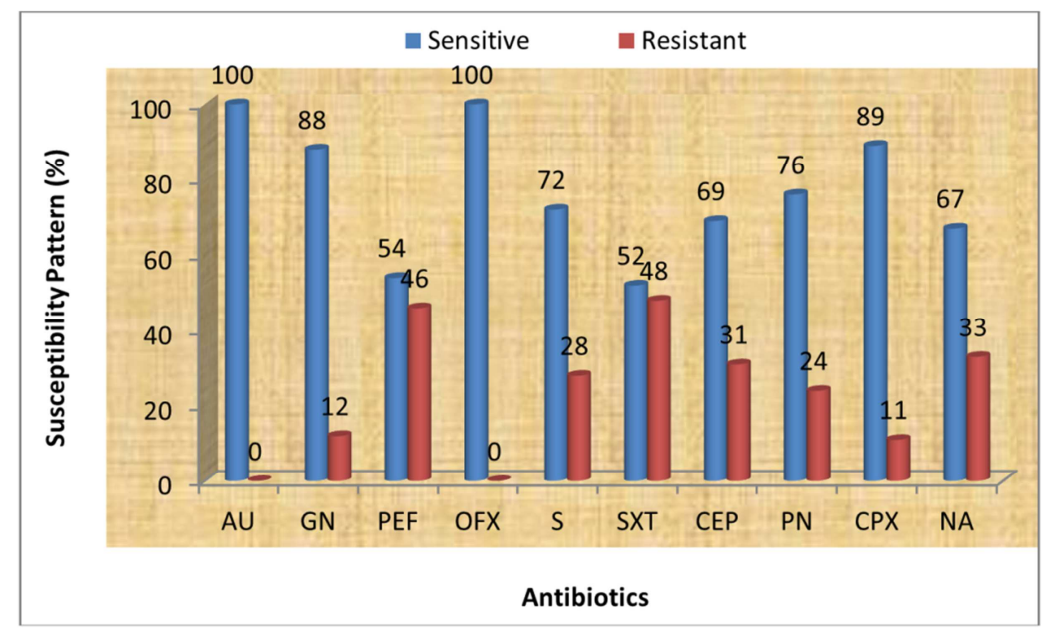

Figure 6. Pre-curing Antibiotic Susceptibility Pattern of B. subtilis isolates.

$\mathrm{PEF}=$ Pefloxacin $(10 \mu \mathrm{g}), \mathrm{OFX}=$ Ofloxacin $(10 \mu \mathrm{g}), \mathrm{S}=$ Streptomycin $(30 \mu \mathrm{g}), \mathrm{SXT}=$ Sulfamethoxazole-Trimethoprim $(30 \mu \mathrm{g}), \mathrm{CEP}=\mathrm{Cephalexin}(10 \mu \mathrm{g})$, $\mathrm{NA}=$ Nalidixic acid, $\mathrm{CPX}=$ Ciprofloxacin $(10 \mu \mathrm{g}), \mathrm{PN}=$ Ampicilin $(30 \mu \mathrm{g}), \mathrm{AU}=$ Amoxicillin-Clavulanic Acid $(30 \mu \mathrm{g}), \mathrm{GN}=\mathrm{Gentamicin}(10 \mu \mathrm{g})$ 
Further analysis of the nature of antibiotic resistance, revealed it was plasmid mediated, since most of them lost their resistance abilities after curing of the plasmids in each of the previously multi-drug resistant isolates (Table 1). These findings suggest that most of the multidrug resistance observed with $E$. coli and $P$. aeruginosawere plasmid mediated and further buttress the assertion that several resistant genes are plasmid encoded. Several studies within Nigeria have shown that most of the multi-drug resistant isolates of clinical and environmental origins were plasmid mediated [25] [26].

The plasmid DNA fragments were detected in samples of $P$. aeruginosaand E. coli which represented the two Gramnegative bacteria that demonstrated multidrug resistance activity (Plate 1). Plasmids are extra-chromosomal genetic materials capable of self replication and also transferable among different microorganisms. The presence of plasmids confers on the microorganisms extra-abilities, especially against antimicrobial agents or potentials to utilized uncommon nutrient source. Thus, the presence of plasmidborne resistant genes from some isolates from surfaces of hospital door handles is of public health concern.

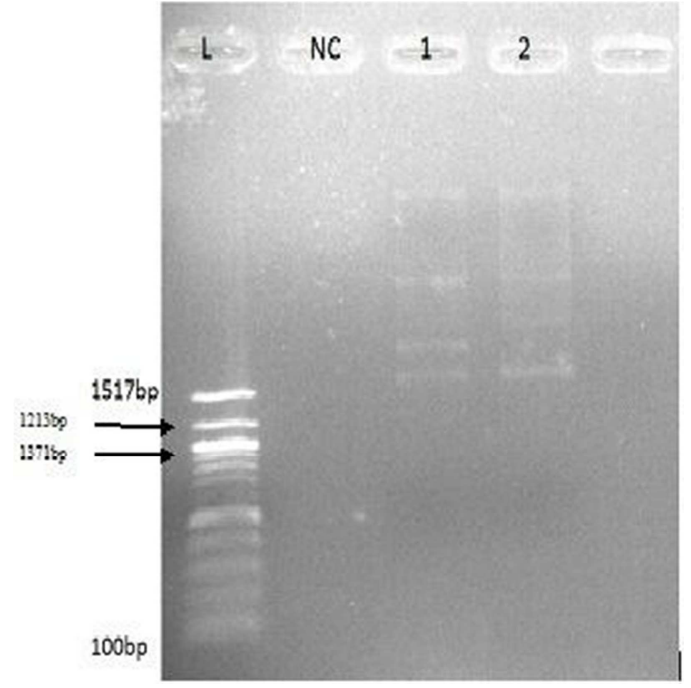

Figure 7. Plasmid DNA of multidrug resistant bacterial isolates analyzed with $1.5 \%$ agarose gel electrophoresis stained with ethidium bromide. $L$ is $100 \mathrm{bp}$ - 1517bp DNA ladder (molecular maker). Sample 1 and 2 are positive for P. aeruginosa and E. coli with bands at $1371 \mathrm{bp}$ and $1213 \mathrm{bp}$. NC is a negative plasmid DNA template control.

Table 1. Post-curing antibiotic susceptibility testing of bacterial pathogens isolated.

\begin{tabular}{|c|c|c|c|c|c|c|c|c|c|c|}
\hline Isolate & PEF & OFX & $\mathbf{S}$ & SXT & CEP & NA & CPX & PN & $\mathbf{A U}$ & GN \\
\hline P. aeruginosa & $\mathrm{S}$ & $\mathrm{S}$ & $\mathrm{S}$ & $\mathrm{S}$ & $\mathrm{S}$ & $\mathrm{R}$ & $\mathrm{S}$ & $\mathrm{S}$ & $\mathrm{S}$ & $\mathrm{S}$ \\
\hline E. coli & $\mathrm{S}$ & $\mathrm{S}$ & $\mathrm{S}$ & $\mathrm{S}$ & $\mathrm{S}$ & $\mathrm{R}$ & $\mathrm{S}$ & S & $\mathrm{S}$ & $\mathrm{S}$ \\
\hline
\end{tabular}

$\mathrm{R}=$ Resistant (zone of bacterial inhibition is $<18 \mathrm{~mm}$ and $\mathrm{S}=$ Sensitive (zone of bacterial inhibition is $>18$ )

$\mathrm{PEF}=$ Pefloxacin $(10 \mu \mathrm{g}), \mathrm{OFX}=$ Ofloxacin $(10 \mu \mathrm{g}), \mathrm{S}=$ Streptomycin $(30 \mu \mathrm{g}), \mathrm{SXT}=$ Sulfamethoxazole-Trimethoprim $(30 \mu \mathrm{g}), \mathrm{CEP}=\mathrm{Cephalexin}(10 \mu \mathrm{g})$, $\mathrm{NA}=$ Nalidixic acid, $\mathrm{CPX}=$ Ciprofloxacin $(10 \mu \mathrm{g}), \mathrm{PN}=$ Ampicilin $(30 \mu \mathrm{g}), \mathrm{AU}=$ Amoxicillin-Clavulanic Acid $(30 \mu \mathrm{g}), \mathrm{GN}=\mathrm{Gentamicin}(10 \mu \mathrm{g})$

\section{Conclusion}

This study has shown that most of the Gram-negative isolates from UBTH door handle surfaces are resistant to most clinical antibiotics. The most resistant isolates were the two Gram-negative bacteria, E. coli and P. aeruginosa, though remarkable antibiotic resistance activities were also found with the Gram-positive isolates. The antibiotic resistance observed with $E$. coli and P. aeruginosa, particularly, was found to be plasmid-mediated since they became susceptible after curing of their plasmids. The danger associated with this is the possibility of cross-transmission of resistant genes among the pathogens, health-workers and patients, thereby creating unfavourable conditions for effective chemotherapy. Hence, it is important to intensify public education on proper personal hygiene, environmental sanitation and development of effective approaches towards limiting the misuse and abuse of antimicrobial agents. Also, continuous surveillance on the antibiogram and molecular typing of isolates from hospital and non-hospital environments are recommended.

\section{References}

[1] Weber D. J., Anderson, D., Rutala, W. A (2013). The role of the surface environment in healthcareassociated infections. Current Opinion 26 (4): 338-344.
[2] Klevens, R. M., Edwards, J. R., Richards, C. L., Horan, T. C., Gaynes, R. P., Pollack, D. A (2007). Estimating health careassociated infections and deaths in US hospitals, 2002. Public Health Reports 122: 160-166.

[3] Weinstein, R. A (1991). Epidemiology and control of nosocomial infections in adult intensive care units. American Journal of Medicine 199:179-184.

[4] Weber D. J., Rutala, W. A., Miller, M. B., Huslage, K, Sickbert-Bennett, E (1991). Role of hospital surfaces in the transmission of emerging health care associated pathogens: Norovirus, Clostridium difficile, and Acinetobacterspecies. American Journal Infection Control 38:25-33.

[5] Hota, B (2004). Contamination, disinfection, and crosscolonization: are hospital surfaces reservoirs for nosocomial infection? Clinical Infection Disease 39:1182-1189.

[6] Boyce, J (2007). Environmental contamination makes an important contribution to hospital infection. Journal of Hospital Infection 65: 50-54.

[7] Bakkali, M. E. L., Hmid, K., Kari, K. E., Zouhdi, M., Mzibri, M. E. L (2015). Characterization of Bacterial Strains and their Resistance Status in Hospital Environment. Journal of Tropical Diseases 4:180. doi:10.4172/2329-891X.1000180.

[8] Wang, H. P., Zhang, H. J, Liu, J., Dong Q., Duan S, Ge, J. Q., Wang, Z. H, Zhang, Z (2017). Antimicrobial resistance of 3 types of gram-negative bacteria isolated from hospital surfaces and the hands of health care workers. American Journal Infection Control 45 (11): e143 e147. doi: 10.1016/j.ajic.2017.06.002. 
[9] Ekhaise, F. O., Ogboghodo, B. I (2011). Microbiological Indoor and Outdoor Air Quality of Two Major Hospitals in Benin City, Nigeria. Sierra Leone Journal of Biomedical Research 3 (3):169-174.

[10] Odigie, A. B., Ekhiase, F. O., Orjiakor, P. I., Omozuwa, S. (2017). The role of door handles in the spread of microorganisms of public health consequences in University of Benin Teaching Hospital (UBTH), Benin City, Edo State. Pharmaceutical Science and Technology 2 (2): 15-21.

[11] Cheesebrough, M. (2006). District Laboratory Practice in Tropical Countries. 2ed. Cambridge University Press, Cambridge, UK. 387pp.

[12] Turnidge, J., Peterson, D. L (2007). Setting and Revising Antibacterial Susceptibility Breakpoints. Clinical Microbiology Reviews 20 (3): 391-408.

[13] Akpi, U. K., Odoh, C. K., Ideh, E. E., Adobu, U. S (2017). Antimicrobial activity of lycoperdonperlatum whole fruit body on common pathogenic bacteria and fungi. African Journal of Clinical and Experimental Microbiology 18 (2): 79 85. doi.org/10.4314/ajcem.v18i2.4.

[14] Akpi, U. K., Odoh, C. K (2017). Antimicrobial activities of Pleurotussquarrosulus on clinical pathogenic bacteria and fungi. Journal of Advanced Microbiology 4 (3) doi: 109734/JAMB/2017/34644.

[15] Clinical Laboratory Standards Institution (CLSI) (2010). Performance Standards for Antimicrobial Susceptibility Testing. Twentieth Informational Supplemented. CLSI document Wayne, PA, USA. M100-S20. 282pp.

[16] Birnboirm H. C., Doly J (1979) "A rapid alkaline extraction procedure for screening recombinant plasmid DNA". Nucleic Acids Research 7:1513-1523.

[17] Wasfy, M. O., Oyofo, B. A., David, J. C., Ismail, T. F., ELGendy, A. M., Mohran, Z. S., Sultan, Y., Peruski, L. F (2000). Isolation and antibiotic susceptibility osSalmonella, Shigella and Campylobacter from enteric infections in Egypt. Journal of Health and Population Nutrition1 8 (1): 33-38.

[18] Nworie, A., Ayeni, J. A., Eze, U. A., Azi, S. O (2012). Bacterial Contamination of Door Handles/Knobs in Selected
Public Conveniences in Abuja Metropolis, Nigeria: A Public Health Threat. Continental Journal of Medical Research 6 (1): $7-11$.

[19] Maori, L., Agbor, V. O., Ahmed, W. A (2013). The prevalence of bacterial organisms on toilet door handles in Secondary Schools in Bokkos L. G. A., Jos, Plateau Sate, Nigeria. IOSR Journal of Pharmacy and Biological Sciences 8 (4): 85-91.

[20] Onwubiko, N. E., Chinyeaka, A. H (2015). Isolation and identification of bacterial Contaminants from door handles in a Tertiary institution in Umuahia, Abia State, Nigeria. Nigerian Journal of Microbiology 29: 3139-3147.

[21] Aloma, A. A., Olonitola, O. S., Jatau, E. D (2016). Isolation, Characterization and Antibiotic Susceptibility Patterns of Pseudomonas aeruginosaand Staphylococcus aureusfrom Hospital Environment in Kaduna Metropolis, Kaduna State. International Journal of Scientific Research 6 (4): 141-146.

[22] Lemmen, S. W., Häfner, H., Zolldann, D., Stanzel, S., Lütticken, R (2004). Distribution of multi-resistant Gramnegative versus Gram-positive bacteria in the hospital inanimate environment. Journal of Hospital Infection 56: 191197.

[23] Hadadi, A., Rasoulinejad, M., Maleki, Z., Yonesian, M. Shirani, A (2008). Antimicrobial resistance pattern of Gramnegative bacilli of nosocomial origin at two University hospitals in Iran. Diagnostic Microbiology and Infectious Disease 60: 301-305.

[24] Friedman, N. D., Temkin, E., Carmeli, Y (2016). The negative impact of antibiotic resistance. Clinical Microbiology and Infection 22 (5): 416-422.

[25] Atata, R. F. Ibrahim, Y. K. E. Giwa, A., Akanbi, A. A. (2013). Antibiotics resistance profile of bacterial isolates from surgical site and hospital environment in a University teaching hospital in Nigeria. Journal of Medicine and Medical Sciences 4 (4): 181-187.

[26] Mbim, E. E., Mboto, C. I., Edet, U. O (2016). Plasmid Profile Analysis and Curing of Multi-drug resistant Bacteria Isolated from Two Hospital Environments in Calabar Metropolis, Nigeria. Asian Journal of Medicine and Health 1 (1):1-11. 